\title{
Examination of the Self-Efficacy of Primary School Teacher Candidates towards First Reading-Writing Education
}

\author{
Hatice Vatansever Bayraktar ${ }^{1}$ \\ ${ }^{1}$ Education Faculty, İstanbul Sabahattin Zaim University, İstanbul, Turkey \\ Correspondence: Hatice Vatansever Bayraktar, Education Faculty, İstanbul Sabahattin Zaim University, İstanbul, \\ Turkey. E-mail: hatice.bayraktar@izu.edu.tr
}

\author{
Received: October 10, 2016 \\ Accepted: October 19, 2016 Online Published: November 16, 2016 \\ doi:10.5539/hes.v6n4p119 \\ URL: http://dx.doi.org/10.5539/hes.v6n4p119
}

This study is a further developed form of the study presented in the XI.European Conference on Social and Behavioral Sciences held on 1-4 September 2016 as an oral declaration.

\begin{abstract}
The aim of this study is to examine the levels of the self-efficacy of primary school teacher candidates towards first reading-writing education and whether they differentiate by various variables. The study is prepared in accordance with the screening model. The universe of this study consists of the primary school teacher candidates who receive education at an Education Faculty of a public university in Istanbul province. As for the sample, it consists of 124 primary school teacher candidates who receive education at the Education Faculty of two public universities in Istanbul province. As for the data collection tool, the "Self-efficacy towards First Reading-Writing Education Scale" developed by Delican (2016) was employed in this study. As a result of the study, there is not a significant difference between the self-efficacies of the primary school teacher candidates towards first reading-writing education depending on their age. The self-efficacy of the primary school teacher candidates towards first reading-writing education creates a significant difference depending on the gender variable. In the preparation, practice and assessment sub-dimensions and on the scale overall, the self-efficacy of females towards first reading-writing education is higher when compared to males. There is a significant difference depending on the variable of the grade in which the primary school teacher candidates receive an education. The self-efficacy of the primary school teacher candidates who study in the $3^{\text {rd }}$ grade towards first reading-writing education is higher when compared to the primary school teacher candidates in the $4^{\text {th }}$ grade. There is not a significant difference between the self-efficacy of the primary school teacher candidates towards first reading-writing education depending on the variable of thinking that teaching first reading-writing to primary school first grades is a hard work. The self-efficacy of the primary school teacher candidates who have previously helped their siblings or nephews during the process of learning first reading and writing towards first reading-writing education is higher in regard to the practice and assessment sub-dimensions and the scale overall. It was observed that the self-efficacy of the primary school teacher candidates towards first reading-writing education in regard to the preparation and practice sub-dimensions and the scale overall was high; the self-efficacy of the primary school teacher candidates towards first reading-writing education according to the assessment sub-dimension was at a quite high level.
\end{abstract}

Keywords: primary school teacher candidate, first reading writing, the self-efficacy of first reading-writing education

\section{Introduction}

Primary school teachers are taught how and with which methods individuals are introduced reading and writing skills with the First Reading and Writing Teaching course in the bachelor's degree program of classroom teaching. The first reading and writing course was included in the Turkish Teaching course in the 1983-1984 program as 2 lesson hours. It was included as "Teaching Reading and Writing" course in the program implemented between 1989 and 1992 as 2 lesson hours in the 5th semester. It was included in the 1998 program as a 3 -credit lesson, 2 hours of which consisted of practice and 2 hours of theory; while it turned into a 3-credit lesson, 3 hours of which consisted of theory in the 2006 program. So, practice was not included in the 2006 program (YÖK, 2007). 
The content of First Reading and Writing Teaching course consists of the following in summary (YÖK, 2007): listening, speaking, visual reading and visual presentation, and the definition and processes of primary reading and writing learning areas, the effect of the features of Turkish on the teaching of first reading and writing, aims and principles of the first reading and writing teaching, basic features of the teacher and students of the primary grade, materials and tools used in the teaching of the first reading and writing teaching, methods used in the first reading and writing teaching.

Akyol (2007) states that teachers who are responsible for introducing reading and writing skills to individuals should have a good level of the knowledge and skills on the first reading and writing teaching. In this sense, it is necessary to raise many primary school teachers within the scope of the first reading and writing teaching course. There are students who cannot start reading and writing and have difficulty in learning reading and writing in the classrooms of teachers who teach many primary grades. Primary school teachers who train themselves well within the scope of the first reading and writing teaching course can minimize the problems on the first reading and writing by approaching these students with different methods and techniques.

The sufficiency of primary school teachers and primary school teacher candidates in the process of first reading and writing teaching is important in terms of the success expected from students. In this sense, one of the factors affecting success in the process of first reading and writing teaching is the self-efficacy perception of primary school teachers and primary school teacher candidates on the teaching of first reading and writing.

According to Bandura (1977), the self-efficacy beliefs of individuals are defined as "the beliefs of individuals in their capacity to organize and successfully realize the activity or action necessary to show a particular performance" (Çapri \& Kan, 2006, p. 49).

Self-efficacy is about how well individuals can do the actions that are necessary to cope with possible situations. These judgments affect the choice of the environmental organization of correct or incorrect activities (B1kmaz, 2002; Delican, 2016).

Broad definition of self-efficacy can be stated as the power to produce an effect (Lacour \& Wilkerson, 1991). To be more specific, Henk and Melnick (1995) cite Bandura's definition which describes perceived self-efficacy as a person's judgments of his or her ability to successfully participate in an activity and the effect this perception has on future activities. In other words, students with positive self-efficacies feel in control of their learning situation and believe they have the capabilities necessary to succeed. Students with poor self-efficacies do not feel in control and believe they do not have capabilities for success. Students' perceptions about their abilities influence how they behave, their thought patterns, and their emotional reactions in difficult situations (Bandura, 1984). Someone with a high self-efficacy is confident and motivated to work toward a learning goal, while a student with a low self-efficacy is not motivated and finds working toward a particular goal very difficult. It is partly through perceptions of self-efficacy that one chooses what to do, how much effort to expend, and how long to persevere at a particular task (Bandura \& Cervone, 1983; Scott, 1996).

Kuzgun (2003) stated that self-efficacy belief is a result of an individual's capacity, achievements, motivations, and other components that form self-awareness; it indicates whether the next behavioural attempt will initiate a behavior, or if an already initiated behavior will continue (Bıkmaz, 2006; Saka et al., 2016).

Self-efficacy is individuals' level of self-confidence in their abilities to manage certain tasks (Bandura, 1997), and it influences how people think, act and motivate themselves (Bandura, 1995). Bandura (1994) emphasized the importance of self-efficacy by suggesting that individuals' motivation and acts are dependent on what they believe rather than the actual situation. Pajares (1996) also said that self-efficacy has a big influence on motivation and behaviors.

Teachers' self-efficacy beliefs have been suggested to be able to significantly affect their classroom practices, particularly their teaching, opinions and tendencies to realize teaching, teaching environments (Ashton \& Webb, 1986). Studies on teachers' self-efficacy beliefs (Ashton, 1984; Gibson \& Dembo, 1984; Ramey \& Shroyer, 1992) shows that teachers' self-efficacy beliefs have a considerable effect on their teaching style, classroom behavior, openness to new ideas, and development of new teaching attitudes. Teachers who have high self-efficacy are believed to be able to enhance student motivation and help them raise their success levels through consideration of students' needs and adoption of a student-centered approach (Ashton \& Webb, 1986; Tschannen-Moran et al., 2002).

Upon examining the studies conducted on the subject, the studies titled "Opinions of the primary school teachers graduated from the department of classroom teaching and primary school teachers from other sources on first reading and writing teaching" made by Sadioğlu (2005), "The sufficiency of the primary school teachers from 
outside the field on teaching first reading and writing and the problems they encounter" by Nargül (2006), "Examination of the knowledge levels and attitudes of classroom teaching last grade students on first reading and writing teaching" by Üst (2015), "Development of the Attitude Scale on the First Reading and Writing Teaching Course" by Arslan and Aytaç (2010), "First Reading and Writing Teaching Methods" by Vatansever-Bayraktar (2016), "Research on the Level of Sufficiency of Classroom Teaching Last Grade Students on Teaching First Reading and Writing with the Sound-Based Sentence Method by the Constructivist Approach" by Dedeli (2008), "A Suggestion on Classroom Teaching Department First Reading and Writing Teaching Lesson by Student Views" performed by Yıldırım and Demirtaş (2008), and "The Relations between the Academic Success, Meta-Cognitive Awareness Levels, Thinking Styles and Attitudes of Primary school teacher candidates in the First Reading and Writing Teaching Course" by Kızılaslan-Tunçer (2013), "An Analysis of the Relationship between High School Students' Self-efficacy, Metacognitive Strategy Use and their Academic Motivation for Learn Biology" by Aydın (2016) were encountered. However, no study that examines the self-efficacy of primary school teacher candidates on first reading and writing teaching was encountered. In this context, it is believed that this study that is performed in order to determine the level of self-efficacy of primary school teachers on the first reading and writing teaching and whether it varies by other variables will contribute to the field.

\subsection{Purpose of the Study}

The aim of this study is to determine the level of the self-efficacy of primary school teachers on the first reading and writing teaching, and whether it varies by the variables of classroom, age, personal question 1 (thinking that it is hard to teach Primary school first grade students how to read and write) and personal question 2 (Previously having helped one's siblings or nephews in the process of first reading and writing).

\section{Method}

\subsection{Research Model}

The research was prepared by the screening model as it tries to determine the existing situation. Screening models are research approaches that aim to describe a past or existing situation as it is (Karasar, 2004).

\subsection{Universe and Sample}

The universe of the research consists of the primary school teachers studying at the Faculty of Education at a state university in Istanbul province. The sample consists of 124 primary school teachers studying at the Faculty of Education of two state universities in Istanbul province.

\subsection{Data Collection Tool}

The "Self-efficacy towards First Reading-Writing Education Scale" developed by Delican (2016) was used in the study as a data collection tool. The scale consists of 25 items and 3 sub-dimensions. According to the result of the exploratory factor analysis, the form that consists of 25 items and 3 sub-dimensions explains $51.12 \%$ of the total variance. The scale consists of the sub-dimension of preparation, practice, and evaluation. While the Cronbach's alpha reliability coefficient for the whole scale is .90 , the Cronbach's alpha reliability coefficients are between .77 and .90 for each sub-dimension.

\subsection{Data Analysis}

The level of the self-efficacy of primary school teachers on the first reading and writing teaching was determined by calculating the arithmetic mean and standard deviation.

The Mann-Whitney U Test was used to determine whether the self-efficacy of primary school teachers on the teaching of the first reading and writing varies by gender, the grade they study and personal question 1 (thinking that it is hard to teach Primary school first grade students how to read and write); the Kruskal-Wallis H Test was performed in order to determine whether it varies by the age variable, and the t-test was performed in order to determine whether it varies by personal question 2 (Previously having helped one's siblings or nephews in the process of first reading and writing). 


\section{Findings}

Table 1. Findings on the gender of primary school teacher candidates

\begin{tabular}{ccccc}
\hline Gender & Frequency & Percent & Valid percent & Cumulative percent \\
\hline Female & 97 & 78,2 & 78,2 & 78,2 \\
Male & 27 & 21,8 & 21,8 & 100,0 \\
Total & 124 & 100,0 & 100,0 & \\
\hline
\end{tabular}

According to Table 1, the findings about gender of primary school teacher candidates show that 97 (78.2\%) of the primary school teachers are female and $27(21.8 \%)$ are male.

Table 2. Findings on the variable of the grade at which primary school teacher candidates study

\begin{tabular}{ccccc}
\hline Grade & Frequency & Percent & Valid percent & Cumulative percent \\
\hline 3 & 110 & 88,7 & 88,7 & 88,7 \\
4 & 14 & 11,3 & 11,3 & 100,0 \\
total & 124 & 100,0 & 100,0 & \\
\hline
\end{tabular}

According to Table 2, the findings about grade of primary school teacher candidates show that $110(88.7 \%)$ of the primary school teachers study at 3rd grade and $14(11.3 \%)$ study at 4 th grade.

Table 3. Findings on the age variable of primary school teacher candidates

\begin{tabular}{ccccc}
\hline Age & Frequency & Percent & Valid percent & Cumulative percent \\
\hline $19-20$ & 28 & 22,6 & 22,6 & 22,6 \\
$21-22$ & 83 & 66,9 & 66,9 & 89,5 \\
$23-24$ & 8 & 6,5 & 6,5 & 96,0 \\
$25-26$ & 2 & 1,6 & 1,6 & 97,6 \\
$27-28$ & 1 &, 8 &, 8 & 98,4 \\
29 ve üzeri & 2 & 1,6 & 1,6 & 100,0 \\
Total & 124 & 100,0 & 100,0 & \\
\hline
\end{tabular}

According to Table 3, the findings about age of primary school teacher candidates show that 28 (22.6\%) 19-20 age, $83(66.9 \%)$ 21-22 age, $8(6.5 \%) 23-24$ age, 2 (1.6\%) 25-26 age, $1(0.8 \%) 27-28$ age, $2(1.6 \%)$ are 29 age and over.

Table 4. Findings on the variable of personal question 1 (thinking that it is hard to teach first-grade primary school students how to read and write) of primary school teacher candidates

\begin{tabular}{ccccc}
\hline Personal Question 1 & Frequency & Percent & Valid percent & Cumulative percent \\
\hline Yes & 105 & 84,7 & 84,7 & 84,7 \\
No & 19 & 15,3 & 15,3 & 100,0 \\
Total & 124 & 100,0 & 100,0 & \\
\hline
\end{tabular}

According to Table 4, findings on the variable of personal question 1 (Thinking that it is hard to teach first-grade primary school students how to read and write) are shown for primary school teacher candidates. 105 (84.7\%) of the primary school teachers think that it is hard to teach first-grade primary school students how to read and 
write; $19(15.3 \%)$ of the primary school teachers think that it is not hard to teach first-grade primary school students how to read and write.

Table 5. Findings on the variable of personal question 2 (previously having helped one's siblings or nephews in the process of first reading and writing) of primary school teacher candidates

\begin{tabular}{ccccc}
\hline Personal Question 2 & Frequency & Percent & Valid percent & Cumulative percent \\
\hline Yes & 74 & 59,7 & 59,7 & 59,7 \\
No & 50 & 40,3 & 40,3 & 100,0 \\
Total & 124 & 100,0 & 100,0 & \\
\hline
\end{tabular}

According to Table 5, findings on the variable of personal question 2 (Previously having helped one's siblings or nephews in the process of first reading and writing) are shown for primary school teacher candidates. 74 (59.7\%) of the primary school teacher candidates who helped previously one's siblings or nephews in the process of first reading and writing); $50(40.3 \%)$ of the primary school teacher candidates didn't helped previously one's siblings or nephews in the process of first reading and writing.

Table 6. General averages of primary school teacher candidates on their self-efficacy perceptions of teaching first reading and writing

\begin{tabular}{lccc}
\hline Sub-dimensions & $\mathrm{N}$ & $\mathrm{X}$ & $\mathrm{Sd}$ \\
\hline Preparation sub-dimension & 124 & 4.1909 & .76635 \\
Practice sub-dimension & 124 & 4.1465 & .56213 \\
Assesment sub-dimension & 124 & 4.2440 & .65213 \\
Total scale & 124 & 4.1742 & .56601 \\
\hline
\end{tabular}

According to preparation $(X=4.19)$ and practice $(X=4.14)$ sub-dimensions and total $(X=4.17)$ of scale, self-efficacy of primary school teacher candidates is high level on the first reading and writing teaching; according to assesment sub-dimensions, self-efficacy of primary school teachers is very high level on the first reading and writing teaching.

Table 7. General averages of primary school teacher candidates on the "preparation" sub-dimension of the self-efficacy scale on the teaching of first reading and writing

\begin{tabular}{cccc}
\hline Preparation sub-dimension & $\mathrm{N}$ & $\mathrm{X}$ & $\mathrm{Sd}$ \\
\hline P1 & 124 & 3.8790 & .89799 \\
P2 & 124 & 4.1210 & .80236 \\
P3 & 124 & 4.2500 & .69405 \\
P4 & 124 & 4.1371 & .87731 \\
P5 & 124 & 4.0726 & .74543 \\
P6 & 124 & 4.2500 & .83252 \\
P7 & 124 & 4.3145 & .74754 \\
P8 & 124 & 4.1855 & .75834 \\
P9 & 124 & 4.5161 & 4.55942 \\
Total scale & 124 & 4.1742 & .56601 \\
\hline
\end{tabular}

The general averages of primary school teacher candidates on the "preparation" sub-dimension of the self-efficacy scale on the teaching of first reading and writing are given in Table 7. Accordingly, «The ability to motivate children to learn how to read and write $(X=3.87)$ » item of the preparation sub-dimension has the lowest, 
while «The ability to prepare materials that fit the gains for using in teaching reading $(\mathrm{X}=4.51)$ » has the highest arithmetic average.

Table 8. General averages on the "practice" sub-dimension of the self-efficacy scale for the first reading and writing teaching of primary school teacher candidates

\begin{tabular}{cccc}
\hline Practice Sub-Dimension & $\mathrm{N}$ & $\mathrm{X}$ & $\mathrm{sd}$ \\
\hline PR 10 & 124 & 4.1129 & .83821 \\
PR 11 & 124 & 4.1290 & .80615 \\
PR 12 & 124 & 4.1532 & .71048 \\
PR 13 & 124 & 4.0081 & .82142 \\
PR 14 & 124 & 4.0000 & .84584 \\
PR 15 & 124 & 4.1371 & .74719 \\
PR 16 & 124 & 4.2419 & .76902 \\
PR 17 & 124 & 4.2339 & .76625 \\
PR 18 & 124 & 4.1048 & .90902 \\
PR 19 & 124 & 4.1532 & .83661 \\
PR 20 & 124 & 4.0968 & .81069 \\
PR 21 & 124 & 4.2903 & .83398 \\
Total scale & 124 & 4.1742 & .56601 \\
\hline
\end{tabular}

The general averages on the "practice" sub-dimension of the self-efficacy scale on teaching first reading and writing of primary school teacher candidates are shown in Table 8. Accordingly, the item of «Ensuring that students can read prosodically (intonation, stress, pauses, articulation and rhythm) $(X=4.00) »$ of the practice sub-dimension has the lowest, while «The ability to use audio tools (listening texts, etc.) in teaching reading and writing $(X=4.29) »$ has the highest arithmetic mean.

Table 9. General averages on the "assessment" sub-dimension of the self-efficacy scale on the first reading and writing teaching of primary school teacher candidates

\begin{tabular}{cccc}
\hline Assessment Sub-Dimension & $\mathrm{N}$ & $\mathrm{X}$ & $\mathrm{Sd}$ \\
\hline $\mathrm{A} 22$ & 124 & 4.2419 & .72550 \\
$\mathrm{~A} 23$ & 124 & 4.3065 & .91222 \\
$\mathrm{~A} 24$ & 124 & 4.2984 & .73230 \\
$\mathrm{~A} 25$ & 124 & 4.1290 & .84553 \\
Total scale & 124 & 4.1742 & .56601 \\
\hline
\end{tabular}

The general averages on the "assessment" sub-dimension of the self-efficacy scale on the first reading and writing teaching of the primary school teacher candidates are shown in Table 9. Accordingly, «The ability to create measurement tools that are suitable for the development properties of the children to assess their reading and writing skills $(X=4.12) »$ has the lowest, while the «Ability to detect students who have difficulty in reading in the process of reading and writing teaching $(\mathrm{X}=4.30) »$ has the highest arithmetic mean. 
Table 10. Mann-Whitney U test result showing the differentiation of the self-efficacy of primary school teacher candidates on the first reading and writing teaching by the gender variable

\begin{tabular}{|c|c|c|c|c|c|c|}
\hline Scale and Sub-Dimensions & Gender & $\mathrm{N}$ & Mean Rank & Sum of Ranks & $\mathrm{U}$ & $\mathrm{P}$ \\
\hline & Female & 97 & 66.94 & 6493.50 & 878.500 & .009 \\
\hline \multirow[t]{3}{*}{ Preparation Sub-Dimension } & Male & 27 & 46.54 & 1256.50 & & \\
\hline & Total & 124 & & & & \\
\hline & Female & 97 & 67.99 & 6595.00 & 777.000 & .001 \\
\hline \multirow[t]{3}{*}{ Practice Sub-Dimension } & Male & 27 & 42.78 & 1155.00 & & \\
\hline & Total & 124 & & & & \\
\hline & Female & 97 & 67.98 & 6594.00 & 778.000 & .001 \\
\hline \multirow[t]{3}{*}{ Assessment Sub-Dimension } & Male & 27 & 42.81 & 1156.00 & & \\
\hline & Total & 124 & & & & \\
\hline & Female & 97 & 67.56 & 6553.50 & 818.500 & .003 \\
\hline \multirow[t]{2}{*}{ Total scale } & Male & 27 & 44.31 & 1196.50 & & \\
\hline & Total & 124 & & & & \\
\hline
\end{tabular}

The Mann-Whitney U test results of primary school teacher candidates on the "Preparation", "Practice" and "Assessment" sub-dimensions of the "Self-efficacy Scale for First Reading and Writing Teaching" of the primary school teacher candidates participating in the study are shown in Table 10. Accordingly, there is a significant difference between the "Preparation $(U=878.500, p<.05)$ "; "Practice $(U=777.000, p<.05)$ " and "Assessment ( $\mathrm{U}=778.000, \mathrm{p}<.05)$ " sub-dimensions of the Self-efficacy Scale on First Reading and Writing Scale" of female and male primary school teacher candidates and the total scores they get from the scale $(\mathrm{U}=818.500, \mathrm{p}<.05)$.

According to Table 10, the self-efficacy of primary school teacher candidates on the teaching of first reading and writing creates a significant difference by the gender variable. The self-efficacy of female primary school teacher candidates on first reading and writing teaching in preparation, practice and assessment sub-dimensions and the scale, in general, is higher when compared to male.

Table 11. Mann-Whitney U test results showing the differentiation of the self-efficacy of primary school teacher candidates on first reading and writing teaching by the grade variable

\begin{tabular}{|c|c|c|c|c|c|c|}
\hline Scale and Sub-Dimensions & Grade & $\mathrm{N}$ & Mean Rank & Sum of Ranks & $\mathrm{U}$ & $\mathrm{P}$ \\
\hline \multirow{3}{*}{$\begin{array}{c}\text { Preparation } \\
\text { Sub-Dimension }\end{array}$} & 3 & 110 & 65.81 & 7239.00 & 406.000 & .004 \\
\hline & 4 & 14 & 36.50 & 511.00 & & \\
\hline & Total & 124 & & & & \\
\hline \multirow{3}{*}{ Practice Sub-Dimension } & 3 & 110 & 65.65 & 7222.00 & 423.000 & .006 \\
\hline & 4 & 14 & 37.71 & 528.00 & & \\
\hline & Total & 124 & & & & \\
\hline \multirow{3}{*}{$\begin{array}{c}\text { Assessment } \\
\text { Sub-Dimension }\end{array}$} & 3 & 110 & 65.65 & 7222.00 & 423.000 & .006 \\
\hline & 4 & 14 & 37.71 & 528.00 & & \\
\hline & Total & 124 & & & & \\
\hline \multirow{3}{*}{ Total scale } & 3 & 110 & 65.56 & 7211.50 & 433.500 & .008 \\
\hline & 4 & 14 & 38.46 & 538.50 & & \\
\hline & Total & 124 & & & & \\
\hline
\end{tabular}


The Mann-Whitney U test results on the total scores obtained by primary school teacher candidates from the "Preparation", "Practice" and "Assessment" sub-dimensions of the "Self-efficacy Scale on First Reading and Writing Teaching" of primary school teacher candidates participating in the study are shown in Table 11 . Accordingly, there is a significant difference between the "Preparation ( $\mathrm{U}=406.000, \mathrm{p}<.05)$ "; "Practice $(\mathrm{U}=423.000, \mathrm{p}<.05)$ "; "Assessment $(\mathrm{U}=423.000, \mathrm{p}<.05)$ " sub-dimensions of the "Self-efficacy Scale on First Reading and Writing Teaching" by the year they study and the total scores they got from the scale $(\mathrm{U}=433.500$, $\mathrm{p}<.05)$.

According to Table 11, there is a significant difference between primary school teacher candidates by the variable of the grade they study at. The self-efficacy of primary school teacher candidates studying at the third grade on first reading and writing teaching is higher than that of the primary school teachers studying at the fourth grade.

Table 12. Kruskal-Wallis H test results showing the differentiation of the self-efficacy of primary school teacher candidates on first reading and writing by the variable of age

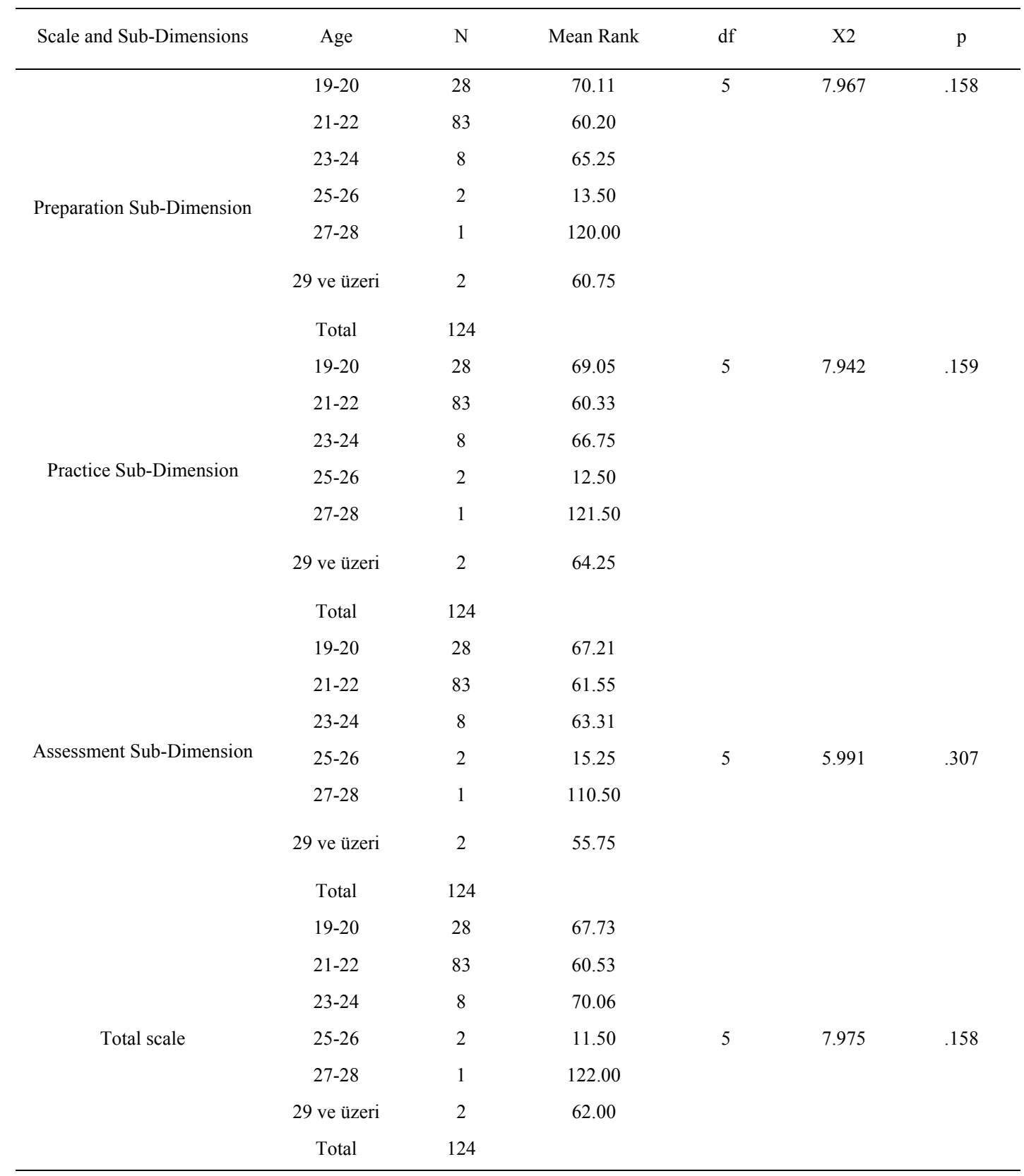


The Kruskal-Wallis test result of the sub-dimensions of "Preparation", "Practice" and "Assessment" of the "Self-efficacy Scale on First Reading and Writing Teaching" of primary school teacher candidates participating in the study and the total scores they obtained from the scale are shown in Table 12. Accordingly, there is no significant difference between the "Preparation [X2 (5)=7.967, P>.05]"; "Practice [X2 (5)=7.942, P>.05]"; "Assessment $[\mathrm{X} 2(5)=5.991, \mathrm{P}>.05]$ " sub-dimensions of the "Self-efficacy Scale on First Reading and Writing Teaching" and the total scores they obtained from the scale $[\mathrm{X} 2(5)=7.975, \mathrm{P}>.05]$ by the ages of primary school teacher candidates.

Table 13. Mann-Whitney U test results showing the differentiation of the self-efficacy of primary school teacher candidates on first reading and writing teaching by the variable of personal question 1

\begin{tabular}{|c|c|c|c|c|c|c|}
\hline Scale and Sub-Dimensions & $\begin{array}{c}\text { Personal } \\
\text { Question } 1\end{array}$ & $\mathrm{~N}$ & Mean Rank & Sum of Ranks & $\mathrm{U}$ & $\mathrm{P}$ \\
\hline \multirow{3}{*}{$\begin{array}{c}\text { Preparation } \\
\text { Sub-Dimension }\end{array}$} & Yes & 105 & 60.50 & 6353.00 & 788.000 & .145 \\
\hline & No & 19 & 73.53 & 1397.00 & & \\
\hline & Total & 124 & & & & \\
\hline \multirow{3}{*}{ Practice Sub-Dimension } & Yes & 105 & 61.24 & 6430.50 & 865.500 & .359 \\
\hline & No & 19 & 69.45 & 1319.50 & & \\
\hline & Total & 124 & & & & \\
\hline \multirow{3}{*}{$\begin{array}{c}\text { Assessment } \\
\text { Sub-Dimension }\end{array}$} & Yes & 105 & 60.51 & 6353.50 & 788.500 & .142 \\
\hline & No & 19 & 73.50 & 1396.50 & & \\
\hline & Total & 124 & & & & \\
\hline \multirow{3}{*}{ Total scale } & Yes & 105 & 60.60 & 6362.50 & 797.500 & .165 \\
\hline & No & 19 & 73.03 & 1387.50 & & \\
\hline & Total & 124 & & & & \\
\hline
\end{tabular}

The Mann-Whitney U test result on the "Preparation", "Practice" and "Assessment" sub-dimensions of the "Self-efficacy Scale on First Reading and Writing Teaching" of the primary school teacher candidates participating in the study and the total scores they obtained from the scale are shown in Table 13. Accordingly, there is no significant difference between the "Preparation $(U=788.000, p>.05)$ "; "Practice $(U=865.500, p>.05)$ "; and "Assessment ( $\mathrm{U}=788.500, \mathrm{p}>.05)$ " sub-dimensions of the Self-efficacy Scale on First Reading and Writing Teaching" by the variable of thinking that it is hard to teach first reading and writing to the primary school first-grade students and the total scores they obtained from the scale $(U=797.500, p>.05)$.

Table 14. The T-Test results showing the differentiation of the self-efficacy of primary school teacher candidates on first reading and writing teaching by the variable of personal question 2

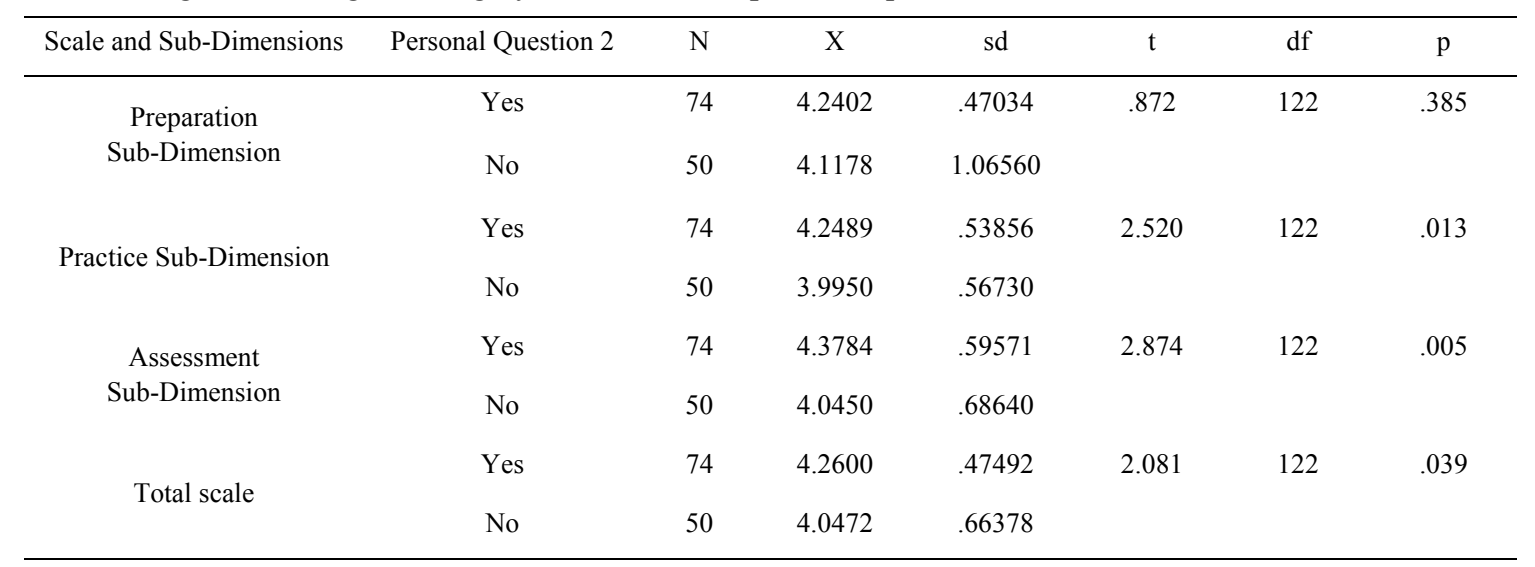


As is seen in Table 14, there is no statistically significant difference between the Self-efficacy perceptions of primary school teacher candidates who previously helped and did not help their siblings or nephews in the process of first reading and writing teaching on First Reading and Writing Teaching by the preparation sub-dimension of the Self-efficacy Scale on First Reading and Writing Teaching [t $(122)=.872, \mathrm{P}>.05]$.

As can be seen in Table 14, there is a statistically significant difference between the practice sub-dimension $t$ $(122)=2.520, \mathrm{P}<.05]$; assessment sub-dimension $[\mathrm{t}(122)=2.874, \mathrm{P}<.05]$ and the overall of the Self-efficacy Scale on First Reading and Writing Teaching between the Self-efficacy perceptions of the primary school teacher candidates who previously helped and did not help their siblings or nephews on First Reading and Writing Teaching. Accordingly, the self-efficacy of the primary school teacher candidates who previously helped their siblings or nephews in the process of first reading and writing on first reading and writing teaching is higher when compared to the sub-dimension of practice and assessment and the overall scale.

\section{Conclusion, Discussion and Suggestions}

The research results are presented below in the light of the data and findings obtained in the research.

It was seen that the self-efficacy of primary school teacher candidates on first reading and writing teaching by the preparation and practice sub-dimensions and the overall scale is high, and the self-efficacy of primary school teacher candidates on first reading and writing teaching by the assessment sub-dimension is very high.

As a result of the study, there is no significant difference between the self-efficacy of primary school teacher candidates on first reading and writing teaching by their ages.

The self-efficacy of primary school teacher candidates on first reading and writing teaching constitutes a significant difference by the gender variable. The self-efficacy of the girls on first reading and writing teaching in the preparation, practice and self-efficacy sub-dimensions and the overall scale is higher than that of the boys.

There is a significant difference by the variable of the grade at which primary school teacher candidates study. The self-efficacy of the primary school teacher candidates studying at the 3rd grade on first reading and writing teaching is higher than the primary school teacher candidates studying at the 4th grade.

There is no difference between the self-efficacy of primary school teacher candidates on first reading and writing teaching by the variable of thinking whether it is a hard job to teach primary school first-grade students first reading and writing.

The self-efficacy of primary school teacher candidates who previously helped their siblings or nephews in the process of first reading and writing teaching on first reading and writing teaching regarding the practice and assessment sub-dimensions and the overall scale is higher.

According to the findings of the study carried out by Yıldırım and Demirtaş (2008), the students who participated in the practice of first reading and writing stated that practical reading and writing teaching would be beneficial by expressing that they felt more relaxed in teaching reading and writing and they knew what to do now. The students who took the First Reading and Writing Teaching course theoretically stated that they knew what they would do, but they did not know how to teach reading and writing, and that this lesson should be definitely in the integrity of theory and practice.

As a result of the study they conducted, Üst (2015) and Kizılaslan (2013) stated that the academic success of female primary school teacher candidates on first reading and writing teaching is higher than the academic success of male primary school teacher candidates on first reading and writing teaching.

In the studies they carried out, Gömleksiz (2013) and Kızlaslan (2013) found out that the attitudes of female primary school teacher candidates on first reading and writing teaching lesson are higher than those of male pre-service teachers. The results of this studies support our research.

According to the findings which are obtained from research made by Dedeli (2008), the senior class students of classroom teacher have positively opined with the method of voice based sentence in the point of education of reading-writing. It has been observed that the female students and students who are going on education by day put themselves trust more than the male students and students who are going on education by night and in the event.

In the studies they carried out, Sadioğlu (2005), research results interpreted that the primary school teachers have some difficulties in teaching early reading and writing and some of the teachers graduated from different educational background wants to work about their branches. 
The following suggestions are mentioned in the line with findings of the research:

Primary school teacher candidates, especially those primary school teacher candidates who do their internship at the last grade may minimize the anxieties towards reading and writing teaching, if any, by dealing with a few of the students studying at primary school first grade in the process of reading and writing, and showing special care to those who have difficulty in reading and writing. A student can be chosen during the year, and last grade primary school teacher candidates may have them perform exercises and activities that facilitate the reading and writing of that student. Then, the reading and writing activities at the first grade will have been followed up closely. The development and success of the first-grade students in reading and writing teaching, their advancement, and certain problems, etc., can be observed.

Primary school teacher candidates should be encouraged to help children at primary school such as siblings, nephews, etc. during their education in teaching them reading and writing.

Primary school teacher candidates should also be encouraged to participate in the courses of «Teaching Reading and Writing to Adults» by participating in the relevant seminars, training, and in-service training.

The self-efficacy of primary school teacher candidates on first reading and writing teaching can be examined in terms of different variables with the new studies to be carried out.

This study includes primary school teacher candidates in Istanbul. It can be applied to primary school teacher candidates around Turkey by expanding the sample group in new studies.

This study is a quantitative study. Qualitative studies or studies where quantitative and qualitative studies exist together can be carried out with regard to the study.

New comparative studies that include the relationship between the self-efficacy of primary school teacher candidates and the relative variable to be detected can be carried out.

\section{References}

Akyol, H. (2007). Türkçe ilk okuma yazma ögrretimi (Yeni Programa Uygun 6. Baskı). Ankara: Pegem A Yayıncilik.

Arslan, D., \& Aytaç, A. (2010). İlkokuma Yazma Öğretimi Dersine İlişkin Tutum Ölçeği Geliştirilmesi (Development of Attitude Scale about the Lesson of the Teaching of Primary Reading and Writing). İlkögretim Online, 9(3), 841-850.

Ashton, P. T., \& Webb, R. B. (1986). Making a difference: Teachers'sense of efficacy and student achievement. New York, NY: Longman.

Aydın, S. (2016). An Analysis of the Relationship between High School Students' Self-Efficacy, Metacognitive Strategy Use and their Academic Motivation for Learn Biology. Journal of Education and Training Studies, $4(2), 53-59$.

Bandura, A. (1984). Recycling misconceptions of perceived self-efficacy. Cognitive Therapy and Research, 8 , 231-255. https://dx.doi.org/10.1007/BF01172995

Bandura, A. (1994). Self-efficacy. In V. S. Ramachaudran (Ed.), Encyclopedia of Human Behavior (Vol. 4, pp. 71-81). New York: Academic Press.

Bandura, A. (1995). Exercise of personal and collective efficacy in changing societies. In A. Bandura (Ed.), Self-Efficacy in Changing Societies (pp. 1-45). New York: Cambridge University Pres. https://dx.doi.org/10.1017/CBO9780511527692

Bandura, A. (1997). Self efficacy: The exercise of control. New York: W. H. Freeman and Company.

Çapri, B., \& Kan, A. (2006). Öğretmen Kişilerarası Öz-Yeterlik Ölçeğinin Türkçe Formunun Geçerlik ve Güvenirlik Çalışması. Mersin Üniversitesi Eğitim Fakültesi Dergisi, 1(2), 48-61.

Dedeli, S. (2008). Sinıf öğretmenliği son sınıf öğrencilerinin yapılandırmact yaklaşıma göre ses temelli cümle yöntemiyle ilkokuma ve yazma öğretimi konusunda yeterlilik düzeylerine ilişskin bir araştırma. Yayımlanmamış yüksek lisans tezi, Dokuz Eylül Üniversitesi Eğitim Bilimleri Enstitüsü, İzmir.

Delican, B. (2016). The Development of Self-efficacy Scale towards Reading \& Writing Teaching. TURKISH STUDIES-International Periodical for the Languages, Literature and History of Turkish or Turkic, 11(3), 861-878. 
Gömleksiz, M. N. (2013). Sınıf öğretmeni adaylarının ilkokuma ve yazma öğretimi dersine ilişkin tutumlarının incelenmesi. Turkish Studies - International Periodical for the Languages, Literature and History of Turkish or Turkic, 8(3), 197-211.

Henk, W. A., \& Melnick, S. A. (1995). The Reader Self-Perception Scale (RSPS): A new tool for measuring how children feel about themselves as readers. The Reading Teacher, 48, 470-482.

Karasar, N. (2004). Bilimsel Araştırma Yöntemi. Ankara: Nobel Yayıncılık.

Kızılaslan-Tunçer, B. (2013). The relationship between pre-service teachers' academic achievement toward initial reading writing course, metacognitive awareness level, thinking style and attitudes toward course. Yayımlanmamış doktora tezi, Çanakkale On Sekiz Mart Üniversitesi Eğitim Bilimleri Enstitüsü, Çanakkale.

Lacour, E. D., \& Wilkerson, T. W. (1991). Efficacy in education: A synopsis of the literature, Office of Educational Research and Improvement. U.S. Department of Education.

Nargül, E. (2006). Adequacy of primary school teachers who are assigned to out of the field, first reading and writing education. Yüksek Lisans Tezi, Sakarya Üniversitesi, Sosyal Bilimler Enstitüsü, Sakarya.

Pajares, F. (1996). Self-Efficacy beliefs in academic settings. Review of educational research, 66(4), 543-578. https://dx.doi.org/10.3102/00346543066004543

Ramey-Gassert, L., \& Shroyer, M. G. (1992). Enhancing science teaching self-efficacy in pre-service elementary teachers. Journal of Elementary Science Education, 4, 26-34. https://dx.doi.org/10.1007/BF03173752

Sadioğlu, Ö. (2005). The Opinion of the teachers both graduaded from department of primary school teaching in education faculties and the non education majoring teachers on early reading and writing instruction. Yüksek Lisans Tezi, Uludağ Üniversitesi, Sosyal Bilimler Enstitüsü, Bursa.

Saka, M., Bayram, H., \& Kabapınar, F. (2016). The Teaching Processes of Prospective Science Teachers with Different Levels of Science-teaching Self-efficacy Belief. Kuram ve Uygulamada Eğitim Bilimleri Educational Sciences: Theory \& Practice, 16(3), 915-941. https://dx.doi.org/10.12738/estp.2016.3.0012

Scott, J. (1996). Self-efficacy: A Key to Literacy Learning. Reading Horizons, 36(3), 193-213.

Tschannen-Moran, M., \& Woolfolk-Hoy, A. (2002). The influence of resources and support on teachers' efficacy beliefs. Paper presented at the Annual Meeting of the American Educational Research Association, New Orleans, LA.

Üst, E. (2015). A study on the knowledge levels and attitudes of department of primary school teaching fourth grade students about first reading and writing teaching. Yüksek Lisans Tezi, Atatürk Üniversitesi, Eğitim Bilimleri Enstitüsü, Erzurum.

Vatansever-Bayraktar, H. (2016). First Reading and Writing Teaching Methods. Eurasian Academy of Sciences Eurasian Education \& Literature Journal, 5, 37-62.

Yıldırım, N., \& Demirtaş, Z. (2008). Öğrenci Görüşlerine Dayalı Sınıf Öğretmenliği Bölümü İlk Okuma ve Yazma Öğretimi Dersine İlişkin Bir Öneri. Gaziantep Üniversitesi Sosyal Bilimler Dergisi, 9(3), 681-695.

Yükseköğretim, K. B. (2007). Öğretmen Yetiştirme ve Eğitim Fakülteleri. Ankara: Yükseköğretim Kurulu Yayını.

\section{Copyrights}

Copyright for this article is retained by the author(s), with first publication rights granted to the journal.

This is an open-access article distributed under the terms and conditions of the Creative Commons Attribution license (http://creativecommons.org/licenses/by/4.0/). 